\title{
Sickle-cell disease in pregnant immigrants
}

\author{
A. E. R. BUCKLE \\ F.R.C.S., F.R.C.O.G. \\ Consultant, Department of Obstetrics and Gynaecology, \\ Lewisham General Hospital, London, S.E.13
}

\section{Summary}

Thirteen pregnancies in nine patients with sicklecell disease, sickle-cell/haemoglobin C disease and sickle-cell/thalassaemia are reported. There was one maternal death and one stillbirth. Crises occurred in three of the four patients with sicklecell disease but in only one of the three patients with sickle-cell/haemoglobin $\mathrm{C}$ disease.

\section{Introduction}

The clinical features of sickle-cell disease have been recognized for many years, the disease being described by Herrick (1910), later Sydenstricker (1924) reported on a large series of cases. In 1931, Yater \& Mollari described a case with fatal outcome; Kobak, Stein \& Daro (1941) made a detailed study of pregnancy in association with sickle-cell disease. The demonstration by Pauling et al. (1949) of an abnormal haemoglobin in the erythrocytes of patients with the disease led rapidly to the identification of additional haemoglobin variants and the introduction of filter-paper electrophoresis by Spaet (1953) allowed of identification of abnormal haemoglobins in general hospital practice, so allowing separation of cases which may previously have been included as sickle-cell disease but which were, in fact, cases of sickle-cell/haemoglobin C disease or cases of sickle-cell/thalassaemia.

An increasing number of papers has since appeared dealing with the problem in the pregnant woman (Adams, Whitacre \& Diggs, 1953; Eisenstein, Posner \& Friedman, 1956; Curtis, 1959 ; Abrams \& Schwartz, 1959; Anderson et al., 1960). These papers have described cases occurring in the United States of America and the West Indies and to date there has been little information concerning cases in the United Kingdom (Reiss, 1962 ; Apthorp, Measday \& Lehmann, 1963). Routine ante-natal haemoglobin electrophoresis screening of negro women has been reported from the United States of America (Curtis, 1959 ; Cotter \& Prystowsky, 1963), from the West Indies (Anderson et al., 1960) and from the United Kingdom (Buckle, Hanning \& Holman, 1964). The results obtained from such screening show a comparable incidence of cases of sicklecell disease, sickle-cell/haemoglobin $\mathrm{C}$ disease and sickle-cell/thalassaemia, an incidence of $0.18 \%$ for these three conditions being reported by Buckle et al. (1964) in immigrants into the United Kingdom from West Africa, the West Indies and the Mediterranean littoral. The conditions will, therefore, be infrequently encountered in association with pregnancy and individual ex perience in management necessarily limited. In the present paper, the course, outcome and mans $Z$ agement of thirteen pregnancies in patients with sickle-cell anaemia or variants will be described

\section{The general problem}

It is not within the compass of this paper to detail the problem of sickle-cell diseases. It wils suffice to mention that these disorders, which are inherited, may give rise to symptoms early in life and may involve almost every system in the body.

The basis of the disease is the presence of the abnormal sickle haemoglobin molecule which, in its reduced state, comes out of solution, forming aggregates. A multi-molecular combination of this haemoglobin, being less soluble then single molecules, will form a solid gel, leading to rigidity within the erythrocyte and this rigidity is reflected in distortion of the cell, which becomes a sickle cell. Because of the abnormal shape, the sickle-cell is liable to mechanical destruction and phagocytosis, leading to haemolytic anaemia. The sickle cells can cause damage by blocking blood vessels, the occlusion of small vessels leading to the crises of sickle-cell disease. Infarction may occur by primary occlusion of small vessels by such tangles of erythrocytes or by embolism from necrotic bone marrow. The sickling phenomenon, which occurs with diminished oxygen tension, is favoured by a lowering of $\mathrm{pH}$ and by increase in body temperature. The oxygen tissues may be low enough in most tissues to induce 
sickling, but this requires time and the cells have normally become re-oxygenated before sickling occurs.

The haemoglobinopathy will be severe where only genes for sickle haemoglobin are present. With one gene for sickle haemoglobin and one for haemoglobin C (sickle-cell/haemoglobin C disease), the amount of haemoglobin $S$ is such that molecular aggregation may occur and the life span of the erythrocytes is reduced, though haemolysis is less than in the homozygous sicklecell disease. The condition may remain undiagnosed unless there is superadded stress such as infection or during pregnancy. In sickle-cell/thalassaemia, where haemoglobin $S$ and $F$ are present, the clinical course, particularly during pregnancy, may be benign.

In general, in sickle-cell disease, there will be chronic anaemia, jaundice, weakness, fatigue, bone and joint pain, and abdominal pain. Signs include fever, bone tenderness, occasional splenomegaly, hepatomegaly, underdevelopment and malnutrition. Symptoms date from early childhood and the condition may well have been diagnosed before pregnancy. The same is not necessarily true of sickle-cell/haemoglobin C disease or of sickle-cell/thalassaemia and routine screening of patients likely to be affected is desirable.

\section{Effects of pregnancy on sickle-cell diseases}

There have been conflicting reports on the seriousness of pregnancy occurring in patients with the sickle-cell diseases. Smith \& Conley (1954) suggested that pregnancy was more hazardous in patients with sickle-cell/haemoglobin C disease, a view which received support from papers by Edington (1957) and Molina \& Marks (1957). Eisenstein et al. (1956) reported a postpartum maternal death in a patient with sicklecell disease. Curtis (1959) found no exacerbation of symptoms and no mortality in nine patients with sickle-cell disease, whereas four of sixteen patients with sickle-cell/haemoglobin $\mathrm{C}$ disease died during pregnancy or after delivery; three cases of sickle-cell/thalassaemia had uneventful pregnancies. Anderson and her colleagues, reporting from the West Indies on nine cases of sicklecell disease, seven cases of sickle-cell/haemoglobin $\mathrm{C}$ disease, and one case of sickle-cell/thalassaemia without maternal death during pregnancy or after delivery, agreed that symptoms in sicklecell/haemoglobin $C$ disease might be manifest for the first time during pregnancy but felt that the hazards, in their cases at least, appeared to be less than in other reports.

In general, pregnancy appears not to influence the natural course of sickle-cell disease, whereas haemolytic and infarctive crises may be manifest for the first time in cases of sickle-cell/haemoglobin $\mathrm{C}$ disease during pregnancy. In sickle-cell / thalassaemia, the condition appears to run a benign course during pregnancy. The maternal mortality generally is higher in cases of sicklecell/haemoglobin $\mathrm{C}$ disease.

\section{Effect of sickle-cell diseases on pregnancy}

Spontaneous abortion in $19 \%$ of cases of sicklecell disease and $16.39 \%$ of cases of sickle-cell/ haemoglobin $\mathrm{C}$ disease was reported by Curtis (1959) and the total foetal survival in his series was $52 \%$ in the former condition and $65 \%$ in the latter. Anderson et al. (1961) reported three abortions and two still-births in thirty-nine pregnancies in patients with sickle-cell disease and sickle-cell/ haemoglobin C disease and Reiss (1962), from the United Kingdom, reported four pregnancies in immigrants with sickle-cell/haemoglobin C disease, without foetal loss. He also reported a peri-natal loss of four of six children born to one patient with sickle-cell disease, but this figure must be treated with reserve as the total included one twin and one triplet pregnancy. McCurdy (1964) found no increase in frequency of maternal complications such as pre-eclampsia, antepartum haemorrhage or post-partum infection in such cases, but reported a $34.6 \%$ foetal loss in sickle-cell disease and a $15.5 \%$ loss in sickle-cell/ haemoglobin $\mathrm{C}$ disease.

The increase in peri-natal mortality in these cases may be related to foetal anoxia consequent on sickling in the maternal venous sinuses. Curtis (1959) suggested that, consequent on sluggish maternal flow and variable oxygen tension, the placenta might be an ideal site for clumping of sickle-cells and thrombosis. Both placental biopsy and biopsy of the uterine muscle at the time of Caesarian section have confirmed marked sickling in the maternal vessels in these cases (Buckle, unpublished observation).

\section{Current series}

Nine patients, observed over a total of thirteen pregnancies, form the basis of this paper. The breakdown of the haemoglobin genotype is shown in Table 1. One case (Case 4) did not have this investigation performed until necropsy, death having taken place suddenly, $40 \mathrm{hr}$ after normal vaginal delivery; the remainder were identified by routine ante-natal screening. Brief clinical details are mentioned below and the more important points are summarized in Tables 2 and 3 .

Case 1 (Hospital No. D 41453)

A 34-year-old primigravida from Barbados. 
Genotype SS. There was a history of jaundice since childhood but no other relevant medical history. Ante-natal booking was at 16 weeks of pregnancy and the patient was admitted 1 week later with joint pains. Examination showed hepatomegaly and splenomegaly and there were old scars on the legs. $\mathrm{Hb} 9 \cdot 2 \mathrm{~g} / 100 \mathrm{ml}$. Total bilirubin $1 \cdot 1 \mathrm{~g} / 100 \mathrm{ml}$. Serum iron slightly increased. The patient was commenced on oral alkalies and given supplementary folic acid, $5 \mathrm{mg}$ daily. She was allowed home and no further crises occurred during pregnancy. The haemoglobin level varied between 7.2 and $9.6 \mathrm{~g} / 100 \mathrm{ml}$. Assessment for induction at 39 weeks' gestation showed the cervix to be unfavourable and delivery was effected by lower segment Caesarian section, operation being carried out under general anaesthesia. One pint of blood was transfused during operation and intravenous sodium bicarbonate given in place of oral alkali until the patient was again taking food by mouth. Intravenous magnesium sulphate, $2 \mathrm{ml}$ of $50 \%$ solution, was given 6-hourly from the time of operation for $24 \mathrm{hr}$. A post-operative pyrexia for 3 days was noted and the patient given a course of ampicillin. No organisms were cultured from a urine specimen or from a high vaginal swab. The oral alkali regime was continued until the patient left hospital. The infant was a liveborn male, weighing $2 \cdot 8 \mathrm{~kg}$.

TABLE 1

Haemoglobin genotype of patients and outcome of pregnancy

\begin{tabular}{|c|c|c|c|}
\hline & \multicolumn{3}{|c|}{ Haemoglobin genotype } \\
\hline & SS & $\mathrm{SC}$ & S/Thalassaemia \\
\hline Total cases & 4 & 3 & 2 \\
\hline $\begin{array}{l}\text { Total previous } \\
\text { pregnancies }\end{array}$ & 6 & 4 & 1 \\
\hline $\begin{array}{l}\text { Total pregnancies } \\
\text { currently observed }\end{array}$ & 5 & 5 & 3 \\
\hline Abortions & - & - & - \\
\hline Still-births & 1 & - & - \\
\hline Neonatal deaths & - & - & - \\
\hline Maternal deaths & 1 & - & - \\
\hline $\begin{array}{l}\text { Average birth weight } \\
\text { of new-born infant } \\
\text { (kg) }\end{array}$ & $2 \cdot 54$ & $2 \cdot 68$ & $3 \cdot 1$ \\
\hline
\end{tabular}

Case 2 (Hospital No. D 13410)

A 28-year-old Nigerian, gravida 2. Genotype SS. There was no relevant medical history but the patient was a poor witness. During the first pregnancy (elsewhere), there had been joint and bone pains on numerous occasions. Vaginal delivery at 37 weeks' gestation had resulted inc? the birth of a live female, weight $2.5 \mathrm{~kg}$.

During the second pregnancy, at this hospital, $\frac{\varrho}{3}$ the patient booked into the ante-natal clinic at $\underset{\Omega}{\Phi}$ 20 weeks. There was no hepatomegaly or spleno- $c$ megaly though there were old leg ulcers. $\mathrm{Hb} 9 \mathrm{~g} / \ddot{\Rightarrow}$ $100 \mathrm{ml}$. Oral alkali and supplementary folic acid were commenced. She was admitted at 30 weeks'들 gestation with bone and joint pains, the haemo- $\frac{\overline{ }}{\bar{n}}$ globin at this time being $8.2 \mathrm{~g} / 100 \mathrm{ml}$, with $\mathrm{a} \frac{\bar{\sigma}}{\widehat{D}}$ reticulocyte count of $20 \%$. The total bilirubin $\odot$ level was $0.5 \mathrm{mg} / 100 \mathrm{ml}$. The oral alkali was increased and her condition rapidly settled but $\vec{\circ}$ 3 weeks later there was a sudden rise in tempera- $?$ ture with signs of left lower lobe pulmonary con- $\vec{\omega}$ solidation (? embolic ?pneumonic) and the patient went into premature labour. The foetal heart sounds ceased at the onset of the second stage 3 . of labour and the patient delivered herself of $a+$ fresh still-born male infant, weight $1 \cdot 8 \mathrm{~kg}$. The $\dot{ }$. puerperium was uneventful, alkali therapy being. discontinued at the time of discharge from ${ }_{\mathscr{W}}^{\infty}$
hospital.

The patient again attended 12 months latep when she booked at the ante-natal clinic at $\overrightarrow{7}$ weeks' gestation. Hb $9.2 \mathrm{~g} / 100 \mathrm{ml}$. The alkadi regimen and supplementary folic acid weß commenced but the patient was admitted at 29 weeks' gestation with pain under the left costæ margin. Haemoglobin level at this time was $7 \cdot 5 \frac{6}{6} \vec{\varphi}$ $/ 100 \mathrm{ml}$ and the total bilirubin $4.7 \mathrm{mg} / 100 \mathrm{~m}$. She was treated with intravenous magnesium sulphate during the painful episode and the orả alkali continued. Her symptoms rapidly subsided and the total bilirubin 3 weeks later was under $1 \mathrm{mg} / 100 \mathrm{ml}$. Labour commenced spontaneously $\stackrel{\AA}{\mathbb{D}}$ at 37 weeks' gestation and the patient delivered herself of a live male infant, weight $2 \cdot 3 \mathrm{~kg}$. Alkali was continued until her discharge after a normal puerperium.

\section{Case 3 (Hospital No. D 18709)}

A 29-year-old Jamaican, gravida 3. Genotype SS. There was no relevant previous history obtained but the patient stated that during both previous pregnancies (elsewhere) she had joint pains throughout pregnancy. Term vaginal delivery had taken place, both infants being liveborn.

In her third pregnancy, observed at this hospital, she attended for ante-natal booking at $N$ 12 weeks. There was no hepatomegaly or splenomegaly and no old scarring on the legs. The haemoglobin was $8 \mathrm{~g} / 100 \mathrm{ml}$. She was commenced on alkali and supplementary folic acid and remained well, without crisis, throughout pregnancy, the haemoglobin level varying between $\stackrel{D}{\mathscr{D}}$ 


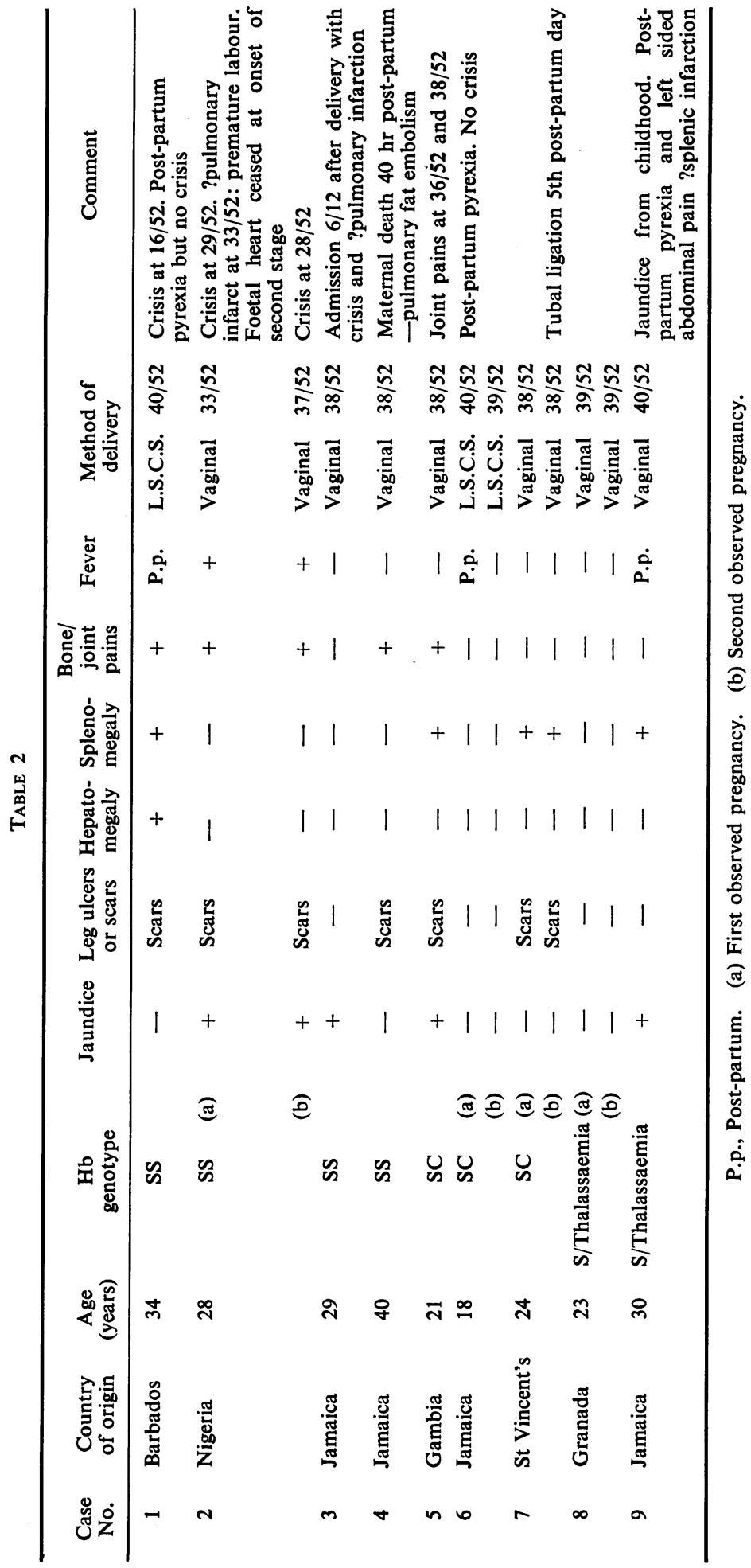


TABLE 3

Laboratory investigations

\begin{tabular}{|c|c|c|c|c|c|c|c|c|}
\hline \multirow{2}{*}{$\begin{array}{l}\text { Case } \\
\text { No. }\end{array}$} & \multirow{2}{*}{\multicolumn{2}{|c|}{$\begin{array}{l}\text { Haemoglobin } \\
\text { genotype }\end{array}$}} & \multicolumn{2}{|c|}{$\begin{array}{c}\text { Haemoglobin } \\
(\mathrm{g} / 100 \mathrm{ml})\end{array}$} & \multirow{2}{*}{$\begin{array}{c}\text { Bilirubin } \\
(\mathrm{mg} / 100 \mathrm{ml}) \\
\text { total } \\
\text { maximum }\end{array}$} & \multirow{2}{*}{$\begin{array}{l}\text { Serum } \\
\text { iron }\end{array}$} & \multirow{2}{*}{$\begin{array}{l}\text { Urine } \\
\text { culture }\end{array}$} & \multirow{2}{*}{ Stool } \\
\hline & & & Lowest & Highest & & & & \\
\hline 1 & SS & & $7 \cdot 2$ & $9 \cdot 2$ & $1 \cdot 1$ & $\begin{array}{l}\text { Slightly } \\
\text { increased }\end{array}$ & E. coli & Negative \\
\hline 2 & SS & $\begin{array}{l}\text { (a) } \\
\text { (b) }\end{array}$ & $\begin{array}{l}7 \cdot 4 \\
7 \cdot 0\end{array}$ & $\begin{array}{l}8 \cdot 7 \\
9 \cdot 8\end{array}$ & $\begin{array}{l}0 \cdot 3 \\
4 \cdot 7\end{array}$ & $\begin{array}{l}\text { Normal } \\
\text { Normal }\end{array}$ & $\begin{array}{l}\text { Negative } \\
\text { Negative }\end{array}$ & $\begin{array}{l}\text { Negative } \\
\text { Negative }\end{array}$ \\
\hline 3 & SS & & $8 \cdot 2$ & $9 \cdot 3$ & $1 \cdot 0$ & $\begin{array}{l}\text { Slightly } \\
\text { increased }\end{array}$ & Negative & Negative \\
\hline 4 & SS & & $10 \cdot 8$ & $12 \cdot 2$ & 1.8 & Normal & Negative & Negative \\
\hline 5 & SC & & $9 \cdot 1$ & $10 \cdot 4$ & - & - & E. coli & Negative \\
\hline 6 & SC & $\begin{array}{l}\text { (a) } \\
\text { (b) }\end{array}$ & $\begin{array}{l}8 \cdot 5 \\
8 \cdot 2\end{array}$ & $\begin{array}{l}9 \cdot 9 \\
9 \cdot 5\end{array}$ & $\begin{array}{l}0.5 \\
1 \cdot 2\end{array}$ & $\begin{array}{l}\text { Normal } \\
\text { Normal }\end{array}$ & $\begin{array}{l}\text { Negative } \\
\text { Negative }\end{array}$ & $\begin{array}{l}\text { Negative } \\
\text { Negative }\end{array}$ \\
\hline \multirow[t]{2}{*}{7} & SC & (a) & $7 \cdot 8$ & 9.9 & 0.6 & $\begin{array}{l}\text { Slightly } \\
\text { decreased }\end{array}$ & Negative & Negative \\
\hline & & (b) & $9 \cdot 4$ & $9 \cdot 6$ & 0.4 & $\begin{array}{l}\text { Slightly } \\
\text { decreased }\end{array}$ & Negative & Negative \\
\hline 8 & \multicolumn{2}{|l|}{$\begin{array}{r}\text { S/Thalassaemia (a) } \\
\text { (b) }\end{array}$} & $\begin{array}{l}10 \cdot 5 \\
11 \cdot 7\end{array}$ & $\begin{array}{l}12 \cdot 0 \\
13 \cdot 7\end{array}$ & - & 二 & $\begin{array}{l}\text { Negative } \\
\text { Negative }\end{array}$ & $\begin{array}{l}\text { Negative } \\
\text { Negative }\end{array}$ \\
\hline 9 & S/Thalassaemia & & $8 \cdot 2$ & $9 \cdot 0$ & $2 \cdot 0$ & Normal & Negative & Negative \\
\hline
\end{tabular}

8.2 and $9.3 \mathrm{~g} / 100 \mathrm{ml}$. Spontaneous onset of labour at 38 weeks was followed by normal vaginal delivery of a live male infant, weight $2.6 \mathrm{~kg}$. The puerperium was uneventful and alkali was discontinued at the time of discharge from hospital (this patient was admitted 9 months later under the care of the physicians with a crisis and pulmonary infarct).

Case 4 (Hospital No. B 81737)

A 40-year-old Jamaican, gravida 4. Genotype SS. No relevant medical history was obtained and the three previous pregnancies had apparently been uneventful, although the patient was a poor historian. The patient attended for antenatal booking at 16 weeks' gestation. There was no hepatomegaly and no splenomegaly and the haemoglobin was $10 \mathrm{~g} / 100 \mathrm{ml}$. Routine screening for abnormal haemoglobins had not been instituted at the time of this patient attending. During the ante-natal period, the haemoglobin level varied between 9.2 and $10.4 \mathrm{~g} / 100 \mathrm{ml}$. She was admitted for bed rest at 36 weeks on account of hypertension and was induced 2 weeks later on this finding. During the time in the ward she had complained once of pain in the arm. Uncomplicated vaginal delivery of a live female, weight $3.2 \mathrm{~kg}$ followed induction. After delivery, the patient complained again of pain in the arms and thighs; $40 \mathrm{hr}$ after delivery, the patient got out of bed, fell to the floor, lost conscious ness and died within a few minutes. Post-mortem examination of the blood confirmed the patien $\overrightarrow{0}$ as being of genotype SS, death resulting from. bone marrow infarction with pulmonary. fal embolism.

\section{Case 5 (Hospital No. D 39069)}

A 21-year-old Gambian, gravida 4. Genotype SS. There was no relevant medical history. The three previous pregnancies (elsewhere) had been $\overrightarrow{\overrightarrow{0}}$ uneventful. In the fourth pregnancy (at this hospital), the patient attended for ante-natal booking at 14 weeks' gestation. There was no hepatomegaly but the spleen was enlarged and there were old scars on the legs. The haemoglobin level was $10.6 \mathrm{~g} / 100 \mathrm{ml}$. She was commenced on oral alkali and supplementary folic acid and remained well throughout pregnancy apart from one attack of fleeting joint pain at 34 weeks' gestation, hospital admission not being necessary. Labour commenced spontaneously at $\frac{D}{2}$ 38 weeks' gestation, the patient delivering herself of a live male infant, weighing $3 \cdot 2 \mathrm{~kg}$. The puer- $\tilde{\sigma}$ perium was uneventful and alkali treatment was discontinued at the time of discharge from hospital.

Case 6 (Hospital No. D 8141)

An 18-year-old Jamaican, gravida 1. Genotype 
SC. There was a history of pneumonia at the age of 16 years. The patient attended for antenatal booking at 20 weeks' gestation, no hepatomegaly, splenomegaly or old leg ulceration being noted. The haemoglobin was $8.5 \mathrm{~g} / 100 \mathrm{ml}$ Alkali treatment with supplementary folic acid was commenced. The haemoglobin level varied between 8.5 and $9.9 \mathrm{~g} / 100 \mathrm{ml}$ during the remainder of pregnancy and no crisis occurred. At term, the cervix was unfavourable for induction; accordingly, lower segment Caesarian section was carried out under general anaesthesia, alkali and magnesium sulphate being given as outlined in Case 1. A live male infant, weighing $3.0 \mathrm{~kg}$ was delivered. The patient had a post-partum pyrexia for which no cause could be found. She was given a course of ampicillin and discharged, afebrile, on the 12th day after operation. There was no crisis during the puerperium.

The patient re-attended for booking at 20 weeks' gestation some 10 months later. She was again put on a similar regimen of management and no crisis occurred during pregnancy. Delivery was effected by elective lower segment Caesarian section at 39 weeks gestation, a live female infant weighing $2.3 \mathrm{~kg}$ being delivered. The post-partum course was uneventful and the regimen of management during and after operation was as previously outlined.

\section{Case 7 (Hospital No. D 2470)}

A 24-year-old gravida 3 from St Vincent's. Genotype SC. The patient gave a history of an Esch. coli septicaemia following a spontaneous abortion, at which time her abnormal haemoglobin state had been discovered. She had one previous full-term pregnancy (elsewhere) and both pregnancy and delivery had apparently been uneventful.

The patient attended for ante-natal booking at 16 weeks' gestation. There was no hepatomegaly, but the spleen was enlarged and there were old scars on the legs. The haemoglobin at booking was $8.6 \mathrm{~g} / 100 \mathrm{ml}$. She was commenced on alkali and supplementary folic acid and the haemoglobin varied between 7.8 and $9.9 \mathrm{~g} / 100 \mathrm{ml}$ during pregnancy; there were no crises. Labour commenced spontaneously at 38 weeks and the patient delivered herself of a live female infant, weight $2.6 \mathrm{~kg}$. The puerperium was uneventful, free from crisis and the haemoglobin after delivery was $10.5 \mathrm{~g} / 100 \mathrm{ml}$.

This patient re-attended for ante-natal booking 18 months later. A similar regimen was instituted and pregnancy was uneventful. She went into labour spontaneously at 37 weeks and delivered a live male infant weighing $2.3 \mathrm{~kg}$. The puerper- ium was uneventful, tubal ligation being carried out on the 5th post-partum day under general anaesthesia.

Case 8 (Hospital No. B 22357)

A 23-year-old gravida 2 from Granada. Genotype S/Thalassaemia. There was no relevant medical history and the previous pregnancy had ended in a spontaneous abortion at 10 weeks. In the current pregnancy, the patient attended for ante-natal booking at 14 weeks. There was no splenomegaly and no hepatomegaly and the haemoglobin level was $10.5 \mathrm{~g} / 100 \mathrm{ml}$. Pregnancy was entirely uneventful and labour commenced spontaneously at 39 weeks' gestation, a live female infant weighing $3.0 \mathrm{~kg}$ being delivered. The puerperium was uncomplicated.

In her second observed pregnancy 5 years later, the pregnancy was again entirely uneventful and vaginal delivery of a living female infant weighing $3 \cdot 3 \mathrm{~kg}$ took place at 39 weeks' gestation. There was no anaemia during pregnancy and the puerperium was uncomplicated.

Case 9 (Hospital No. B 54658)

A 30-year-old gravida 2 from Jamaica. Genotype S/Thalassaemia. There was a long-standing history of jaundice and investigation under the care of the physicians had revealed her abnormal haemoglobin state. In her first pregnancy (elsewhere), there had apparently been no abnormality.

In her second pregnancy, at this hospital, the patient attended ante-natal booking at 24 weeks' gestation. There was no hepatomegaly but the spleen was palpable. The haemoglobin was $9 \mathrm{~g} /$ $100 \mathrm{ml}$. There was a persistent anaemia throughout pregnancy, which was otherwise uneventful. The patient commenced labour spontaneously at 39 weeks and delivered herself of a live female infant, weight $4.0 \mathrm{~kg}$. The puerperium was uneventful.

\section{Patient management during pregnancy}

The patients have been seen at frequent intervals during the ante-natal period and carefully observed, particularly from the haematological point of view, blood examination being carried out at each attendance. An adequate diet, with special regard to a good protein intake, has been advised but, in so far as these patients generally have adequate iron stores (Monitt, 1963), oral iron only was given during pregnancy and no recourse was had to parenteral iron. Serum iron levels have been estimated (see Table 3 ).

As crises may result from a rise in temperature, the patients have been warned to report any illness and have, where necessary, been given anti- 
biotic cover for such illnesses. In addition, routine screening of the urine has been carried out during pregnancy to exclude chronic pyelonephritis, for patients with sickle-cell/haemoglobin C disease have been reported as having this condition more frequently than other patients (McCurdy, 1964). Stool examination has also been routinely carried out (Table 3 ).

The continuing demand on the haemotopoietic function of the bone marrow means that supplementary folic acid should be supplied and this is particularly the case during pregnancy, where there is the additional demand from the foetus. A daily dose of $5 \mathrm{mg}$ of folic acid has therefore been given throughout pregnancy.

As mentioned earlier in this paper, sickling occurs with falling oxygen tension and is favoured by a lowering of the $\mathrm{pH}$ or a rise in the body temperature. Greenberg \& Kass (1958) drew attention to the effect of acidosis on sickling and Lehmann (1963) pointed out that, without local acidosis, stasis or firm intravascular wedging of the sickled blood, infarctive crises do not occur. $\mathrm{He}$ felt that alkali treatment played its part in the prevention of sickling rather than in the treatment of the crisis. Stasis encourages sickling because the cell loses oxygen and there is a rise of acid metabolites, but the greater the alkali reserve, the longer stasis would have to last to result in sickling. Lehmann further pointed out that, for a painful and lasting crisis, the cells have to be bound together by clotting plasma. Intravenous magnesium sulphate may delay the increase in viscosity and also, if clotting has taken place, prevent further strengthening of the clot, so allowing gradual reduction in its size. On this basis he advocated a regimen of intravenous magnesium sulphate during crisis, followed by oral magnesium and this to be followed by a regimen of oral sodium bicarbonate.

Our patients have been kept on oral sodium bicarbonate throughout pregnancy, sufficient being given to keep all urine specimens alkaline. The patients have been instructed to test every specimen with litmus paper and it has been possible to obtain full co-operation on this point. The average amount of sodium bicarbonate given has been $2 \mathrm{~g}$ 6-hourly during the day and $4 \mathrm{~g}$ at night. During crises, the patients have been admitted and alkali treatment, possibly in increased amount, continued and intravenous magnesium sulphate given as outlined above.

Blood transfusion has been avoided whenever possible ; although available at the time of operation, it has only been necessary to transfuse one patient. It was reported by Went \& McIver (1958) that when transfusion took place, there was a diminished reticulocytosis which returned to usual levels when the haemoglobin had returned to the pre-transfusion level.

Management at the time of delivery

Where vaginal delivery has been anticipated, labour, if not commencing spontaneously, has been induced at or shortly before term in order to avoid the additional placental hypoxia which may occur in post-term delivery. After the spontaneous or induced commencement of labour, intravenous dextrose-saline has been commenced, oral alkali continued and intravenous magnesium sulphate given 6-hourly in a dose of $2 \mathrm{ml}$ of a $50 \%$ solution, the regimen continuing throughout labour and for the first $24 \mathrm{hr}$ of the post-partum period, after which time the patient has returned to the oral alkali regimen. If any urine specimen during labour has been of acid reaction, intravenous sodium bicarbonate has been substituted for the oral alkali.

In those cases where elective Caesarian section has been advisable because of the difficulty of induction of labour, an identical routine hast been employed. Anaesthesia has been standard $z$ thiopentone-scoline-gas-oxygen-pethidine, grea? care being taken to avoid hypoxia. It has beem thought advisable to give prophylactic antibiotic to any patient delivered in this way.

\section{Management in the puerperium}

The oral alkali and supplementary folic acid have been continued after delivery until the time of discharge from hospital. The question of continuation beyond this time has not been thought necessary and in many instances not possible as the patients have been difficult to contact. Blood has been taken from the father of the child in order to give some idea of the likely genotype of the child. Contraceptive advice has been given to these, as to all other patients in the unit, but in view of problems in ensuring that oral contraception is taken correctly, intrauterine devices have been preferred. In selected cases, post-partum tubal ligation has been carried out.

\section{Discussion}

Symptoms in sickle-cell disease commence in early childhood and the natural history of the condition is of chronic ill-health with haemolytic anaemia, painful or haemolytic crises interrupting the condition from time to time. In sicklecell/haemoglobin $\mathrm{C}$ disease, symptoms may be manifest for the first time during pregnancy or as a result of infection. The deleterious aspects of the conditions are two-fold, namely the haemo- 
lytic anaemia and the crises. As Lehmann (1963) pointed out, the former is no more severe than in other congenital or acquired haemolytic anaemias and required protection from infection and supplementary folic acid to maintain haemotopoiesis. The infarctive crises, resulting from deoxygenation of the abnormal cells, are favoured by local acidosis, vascular stasis and intravascular wedging of the sickled cells. After Greenberg \& Kass (1958) had drawn attention to the role of acidosis in sickling crises, an alkali regimen was used in treatment (Scott \& Ferguson, 1960). The additional use of magnesium with the object of preventing the conversion of partially sickled and sludged cells into a firm plug was advocated (Anstall et al., 1959; Huntsman, Hurn \& Lehmann, 1960) but it was later reported (Apthorp et al., 1963) that alkali treatment alone was equally effective in the prevention of infarctive episodes, although the latter authors gave intravenous magnesium in the early stages of acute episodes or during operation.

As mentioned earlier in this paper, reports are conflicting on the seriousness of the association of the sickle-cell disease and pregnancy and it is not possible to draw any conclusions from the cases in the present series because of the small number involved. Further reports will be required before firm comment can be made. The impression gained from questioning the patients has been that, although not symptom-free on the regimen outlined, they have been very much less troubled during and after delivery when so managed than when not on alkali treatment. The one maternal death occurred in a patient who had not been managed by the alkali regimen and who died from pulmonary fat embolism shortly after delivery. As this occurs independently of pregnancy, it is not possible to know whether the patient would not have succumbed even if she had been on treatment. The one stillbirth in the series occurred in a patient who went into premature labour after possible pulmonary infarction and the foetal heart ceased shortly before delivery. Later pregnancy in the same patient has been successful.

\section{References}

Abrams, J. \& Schwartz, I.R. (1959) The Sickle-cell diseases in pregnancy. Amer. J. Obstet. Gynec. 77, 1324.

Adams, J.Q., Whitacre, F.E. \& Diggs, L.W. (1953) Pregnancy and sickle-cell disease. Obstet. and Gynec. 2, 335.
Anderson, N., Went, N.L., McIver, J.E. \& Dixon, H.G. (1960) Sickle-cell disease in pregnancy. Lancet, ii, 516.

Anstall, H.B., Huntsman, R.G., LehmanN, H., Hayward, G.W. \& Weitzman, D. (1959) The effect of magnesium on blood coagulation in human subjects. Lancet, i, 814.

Apthorp, G.H., Measday, B. \& LehmanN, H. (1963) Pregnancy in sickle-cell anaemia. Lancet, $\mathbf{i}, 1344$.

Buckle, A.E.R., Hanning, L. \& Holman, C.A. (1964) Routine haemoglobin electrophoresis in at-risk gravid women. J. Obstet. Gynaec. Brit. Cwlth, 71, 923.

Cotter, J. \& Prystowsky, H. (1963) Routine haemoglobin electrophoresis in negro gravidas. Obstet. and Gynec. 22, 610.

Curtis, E.M. (1959) Pregnancy in sickle-cell anaemia, sickle-cell/haemoglobin $\mathrm{C}$ disease and variants thereof. Amer. J. Obstet. Gynec. 77, 1312.

EDINGTON, G.M. (1957) The pathology of sickle-cell/haemoglobin C disease and sickle-cell anaemia. J. clin. Path. 10, 182.

Eisenstein, M.I., Posner, A.C. \& Friedman, S. (1956) Sickle-cell anaemia in pregnancy. Amer. J. Obstet. Gynec. $72,622$.

GreenberG, M.S. \& KASS, E.H. (1958) Studies on the destruction of red blood cells. XIII. Observations on the role of $\mathrm{pH}$ in the pathogenesis and treatment of painful crisis in sickle-cell disease. Arch. intern. Med. 101, 355.

Herrick, J.B. (1910) Peculiar elongated and sickle-shaped red blood corpuscles in a case of severe anaemia. Arch. intern. Med. 6, 517.

Huntsman, R.G., Hurn, B.A. \& LehmanN, H. (1960) Observations on the effect of magnesium on blood coagulation. J. clin. Path. 13, 99.

KobaK, A.L., Stein, P.J. \& Daro, A.F. (1941) Sickle-cell anaemia in pregnancy. A review of the literature and report of six cases. Amer. J. Obstet. Gynec. 41, 811.

LehmaNN, H. (1963) Letter. Brit. med. J. i, 1158.

MCCURDY, P.R. (1964) Abnormal haemoglobins and pregnancy. Amer. J. Obstet. Gynec. 90, 891.

Molina, V., JR \& Marks, S. (1957) Sickle-cell disease in pregnancy with electrophoresis in twenty two cases. Bull. Tulane Med. Fac. 17, 19.

MonITT, E.R. (1963) Sickle-cell haemoglobin C disease. Quantitative determination of iron kinetics and haemoglobin synthesis. Blood, 21, 535.

Pauling, L., Itano, H.A., Singer, S.J. \& Wells, I.C. (1949) Sickle cell anaemia, a molecular disease. Science, 110, 543.

Reiss, H.E. (1962) Discussion. Proc. Roy. Soc. Med. 55, 765.

ScotT, R.B. \& Ferguson, A. (1960) Studies in sickle-cell anaemia. XIV. Management of the child with sickle-cell anaemia. Amer. J. Dis. Child. 100, 85.

Smith, E.W. \& Conley, C.L. (1954) Clinical features of the genetic variants of sickle-cell disease. Bull. John Hopkins Hosp. 94, 289.

SPAET, T.H. (1953) Identification of abnormal haemoglobins by means of paper electrophoresis. J. Lab. clin. Med. 41, 161.

SYDENSTRICKER, V.P. (1924) Further observations on sicklecell anaemia. J. Amer. med. Ass. 83, 12.

WeNT, L.N. \& MCIVER, J.E. (1958) Sickle-cell anaemia in adults and its differentiation from sickle-cell thalassaemia. Lancet, ii, 824.

YATER, W.M. \& MollaRI, M. (1931) The pathology of sickle-cell anaemia. Report of a case with death during an "abdominal crisis". J. Amer. med. Ass. 96, 1671. 